\title{
Penentuan Mutu Kelapa Sawit Menggunakan Metode K-Means Clustering
}

\author{
Andri Nofiar Am ${ }^{1}$, Sarjon Defit ${ }^{2}$, Sumijan $^{3}$ \\ ${ }^{1}$ Politeknik Kampar \\ ${ }^{2,3}$ Fakultas Ilmu Komputer , Universitas Putra Indonesia YPTK \\ E-mail: Andrinofiar90@gmail.com
}

\begin{abstract}
The classification of the quality of palm oil in PT Tasma Puja is still done by laboratory testing and then the data is saved manually in Excel. The method of grouping takes time and allows data to be lost. With the development of knowledge, it can be replaced by a data mining approach that can be used to classify the quality of palm oil based on its standards. The k-Means clustering method can be applied to classify the quality of palm oil based on water, dirt and free fatty acids. The data used is the quality data of palm oil in December 2017 as many as 31 data with criteria of good, very good and not good. The test results contained 3 clusters, namely cluster 0 for good categories amounted to 12 data, cluster 1 for very good category amounted to 13 data and cluster 2 for less good categories amounted to 6 data. The k-Means clustering method can be used for data processing using the concept of data mining in grouping data according to criteria.
\end{abstract}

Kata kunci: Data Mining, K-Means Clustering, Cluster

\begin{abstract}
Abstrak
Pengelompokan mutu minyak kelapa sawit pada PT Tasma Puja masih di lakukan dengan cara uji laboratorium dan selanjutnya data disimpan secara manual di excel. Cara pengelompokan tersebut membutuhkan waktu dan memungkinkan data hilang. Dengan perkembangan ilmu pengetahuan nantinya bisa di gantikan dengan pendekatan data mining yang dapat digunakan dalam mengelompokan mutu minyak kelapa sawit berdasarkan standartnya. Metode k-Means clustering dapat diterapkan untuk mengelompokan suatu kualitas minyak kelapa sawit berdasarkan air, kotoran dan asam lemak bebas. Data yang digunakan adalah data kualitas minyak kelapa sawit pada bulan desember 2017 sebanyak 31 data dengan kriteria baik, sangat baik dan kurang baik. Hasil pengujian terdapat 3 cluster yaitu cluster 0 kategori baik berjumlah 12 data, cluster 1 kategori sangat baik berjumlah 13 data dan cluster 2 kategori kurang baik berjumlah 6 data. Metode $k$-Means clustering dapat digunakan untuk proses pengolahan data menggunakan konsep data mining dalam mengelompokkan data sesuai kriteria.
\end{abstract}

Kata kunci: Data Mining, K-Means Clusting, Cluster

\section{Pendahuluan}

Indonesia merupakan negara yang memiliki banyak lahan pertanian dan perkebunan, salah satunya yaitu kelapa sawit. Salah satu tumbuhan industri penghasil minyak adalah kelapa sawit, baik itu minyak masak, minyak industri, minyak bahan bakar (biodiesel). Jumlah total luas area perkebunan kelapa sawit di Indonesia pada saat ini mencapai 11,9 juta hektar berdasarkan badan pusat statisktik.

Untuk menghitung kualitas minyak kelapa sawit dilakukan uji laboratorium berdasarkan kandungan air, kotoran dan k asam lemak bebas. Salah satu faktor yang mempengaruhi dalam

\footnotetext{
Dikirim : :2019-03-14

Diterima : :2019-03-20

Diterbitkan : 2019-04-01

DOI : https://doi.org/10.29165/komtekinfo.v5i2
} 
kualitas minyak kelapa sawit yaitu kadar Asam Lemak Bebas (ALB). Dimana tandan buah kelapa sawit ini ketika panen kadar ALB nya ini akan meningkat $0.1 \%$ setiap hari, akan tetapi kadar ini tidak boleh lebih dari 2-3\% ketika masuk di pabrik, karena bobot ALB yang baik hanya $3 \%[1]$.

Proses penyimpanan data air, kotoran dan asam lemak bebas yang dihasilkan setiap kali produksi dari hasil uji laboratorium masih disimpan secara manual menggunakan aplikasi microsoft excel. Dengan penyimpanan data tersebut terdapat kelemahan yaitu susahnya dalam melakukan penilaian kualitas produksi minyak kelapa sawit yang dihasilkan. Produksi minyak kelapa sawit yang dilakukan setiap hari pada PT. Tasma Puja menyebabkan banyaknya penyimpanan data yang berdampak pada lamanya waktu yang dibutuhkan untuk mencari hasil terbaik dari setiap kali produksi minyak kelapa sawit.

Dengan perkembangan ilmu pengetahuan yang semakin pesat nantinya, proses penyimpanan data hasil produksi pada PT. Tasma Puja dapat digantikan dengan pendekatan data mining yang digunakan dalam mengelompokan kualitas minyak kelapa sawit berdasarkan bobot yang telah ditetapkan, dengan melakukan pembagian data kedalam kelas atau cluster berdasarkan tingkat kesamaannya. Sehingga Data yang diolah dengan menggunakan data mining menghasilkan pengetahuan atau Knowledge yang baru, dengan bersumber dari data lama hasil produksi minyak kelapa sawit.

\section{Tinjauan Literatur}

Knowledge Discovery in Database (KDD) merupakan suatu metode yang digunakan untuk menganalisis data pada penerapan data mining untuk mencari pengetahuan, dan informasi yang lebih dari sebuah kumpulan data. Knowledge Discovery in Database (KDD) yaitu suatu kegiatan yang terdiri dari beberapa tahapan, seperti Cleaning and Integration, Selection and Transformation, Data mining, dan Evaluation and Interpretation. Pada proses Evaluation and Interpretation ini merupakan cakupan dari proses pemeriksaan baik pola itu atau informasi yang ditemukan bertentangan dengan fakta atau hipotesa sebelumnya. Dalam memilih suatu metode atau algoritma yang digunakan sangat mempengaruhi dari proses dan tujuan dari Knowledge Discovery in Database (KDD) [2].

Data mining merupakan suatu proses penggalian pola dari sekumpulan data yang besar dengan menggunakan teknik tertentu yang menghasilkan nilai lebih, baik itu pengetahuan dan informasi dari data yang belum diketahui. Data mining dapat melakukan satu atau lebih dari teknik pembelajaran komputer, dimana proses tersebut dapat dilakukan secara otomatis ataupun semi otomatis. Pola yang dicari menghasilkan nilai tambah ekonomi dari hasil yang ditemukan [3].

Salah satu teknik pengelompokkan dari data mining adalah clustering. Clustering adalah pengelompokkan sejumlah data atau objek ke dalam cluster sehingga setiap dalam cluster tersebut berisi data yang semirip mungkin dan berbeda dari objek dalam cluster lainnya.Clustering merupakan salah satu teknik pengelompokkan dalam data mining yaitu pengelompokkan sejumlah data ataupun objek ke dalam suatu kelompok atau cluster atau group sehingga setiap data dalam cluster tersebut berisi suatu data yang memiliki kemiripan ataupun berbeda dengan objek dalam cluster yang lain[4].

Algoritma K-Means adalah pengelompokkan data yang berdasarkan titik pusat dari klaster (centroid) yang terdekat dengan data yang merupakan algoritma klasterisasi. Adapun tujuan dari algoritma ini yaitu mengelompokkan data dengan memaksimalkan kemiripan data dalam satu klaster dan meminimalkan kemiripan data antar klaster. Fungsi jarak merupakan ukuran kemiripan yang digunakan dalam klaster, sehingga hasil yang maksimal dari kemiripan data berdasarkan jarak terpendek antara data terhadap titik centroid [5].

Algoritma K-Means merupakan suatu metode yang digunakan untuk menemukan kelompok dari dokumen atau objek yang non-overlapping, dan juga dapat disebut sebagai suatu algoritma yang paling efektif untuk mengelompokkan kumpulan data. Algoritma ini dapat diimplementasikan, dijalankan dan diproses dengan cepat, mudah beradaptasi [6].

Adapun langkah-langkah perhitungan menggunakan algoritma K-Means ini yaitu : 
1. Masukkan jumlah $\mathrm{K}$ cluster, $\mathrm{K}$ disini berarti banyaknya cluster yang ingin dibentuk.

2. Tentukan nilai awal centroid (K pusat cluster) untuk $\mathrm{k}$ cluster dari sejumlah dataset yang bisa dilakukan dengan berbagai cara yang salah satunya dengan secara acak atau random.

3. Semua data/objek dialokasikan ke cluster yang terdekat antara dua objek yang sesuai dengan jarak kedua objek tersebut. Sama halnya dengan kedekatan satu data ke cluster tertentu. Langkah ini dapat dihitung dari jarak tiap data ke tiap pusat cluster (centroid cluster). Untuk menghitung setiap titik pada cluster terdekat bisa menggunakan rumus jarak Euclidean, sebagai berikut :

$D_{(i, j)}=\sqrt{\left(X_{1 i}-X_{1 j}\right)^{2}+\left(X_{2 i}-X_{2 j}\right)^{2}+\cdots+\left(X_{k i}-X_{k j}\right)^{2}}$

Dimana:

$D_{(i, j)=}$ jarak data ke $i$ ke pusat cluster $j$

$X_{k i=}$ Data ke $i$ pada atribut data ke $k$

$X_{k j}=$ Titik pusat ke $j$ pada atribut ke $k$

4. Hitung ulang untuk mencari nilai centroid dari setiap $\mathrm{k}$ cluster dengan jumlah data $\mathrm{m}$ untuk menemukan nilai centroid $K$ cluster yang baru. Adapun titik pusat cluster (centroid cluster) yaitu rata-rata dari semua titik dalam cluster. Adapun cara mencarinya bisa menggunakan median dari data kelompok tersebut [7].

\section{Metodologi Penelitian}

Metodeologi penelitian disini dijabarkan dengan kerangka kerja penelitian. Kerangka kerja merupakan urutan atau uraian alur kerja sistem yang harus diikuti. Penelitian ini akan dilakukan secara berurutan dari awal penelitian sampai hasil yang akan didapatkan dengan menggunakan metode $K$-Means clustering. Adapun kerangka kerja yang harus diikuti untuk penelitian ini dapat dilihat seperti gambar 2 sebagai berikut.

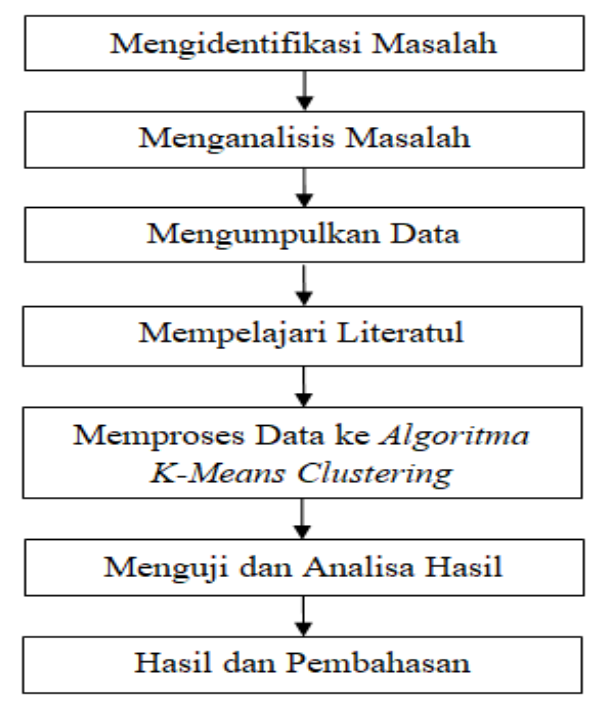

Gambar 1 : Kerangka Kerja Penelitan

Keterangan :

1. Mengidentifikasi Masalah

Masalah yang diidentifikasi dalam penelitian ini adalah mengelompokkan asam lemak bebas untuk menentukan kualitas minyak kelapa sawit yang dihasilkan pada PT. Tasma Puja.

2. Menganalisis Masalah

Analisis masalah adalah untuk dapat memahami masalah yang telah ditentukan ruang lingkup dan batasannya. Dengan menganalisa masalah yang telah ditentukan tersebut, maka diharapkan 
masalah dapat dipahami dengan baik. Proses pengambilan keputusan dalam pengelompokan kualitas minyak kelapa sawit pada PT. Tasma Puja.

3. Mengumpulkan data

Untuk memperoleh data-data yang dibutuhkan dalam proses penulisan tesis ini, maka penulis menggunakan metode-metode sebagai berikut :

a. Studi Kepustakaan (Library Research)

Studi kepustakaan adalah suatu metode pengumpulan data yang dilakukan pada perpustakaan yang harus diperhatikan sumber yang diteliti yaitu buku bacaan yang menjadi pembahasan sumber masalah yang dibahas, dan bahan-bahan yang berhubungan dengan masalah yang diteliti.

b. Pengamatan (Observation)

Untuk mengumpulkan informasi dilakukan pengamatan langsung pada laboratorium yang bertujuan untuk mendapatkan keterangan yang berhubungan dengan objek yang akan diteliti.

c. Dokumentasi

Dokumentasi merupakan cara memperoleh data dan informasi yang dibutuhkan dengan mengumpulkan data dari dokumen perusahaan yang berkaitan dengan proses pengumpulan data.

4. Mempelajari Literatur

Setelah mengumpulkan data yang akan di proses dalam studi literatur ini, terlebih dahulu mengetahui pengetahuan atau knowledge yang akan diterapkan dalam metode ini, literarul yang akan dipelajari ini bersumber dari jurnal-jurnal ilmiah yang di publikasikan di internet.

5. Memproses Data Ke Algoritma $K_{-}$Means Clustering

Setelah melakuan pengumpulan data dan mempelajari literatur, selanjutnya dilakukan proses ke algoritma K-Means Clustering yaitu :

a. Menentukan jumlah cluster

b. Menentukan titik pusat centroid secara random

c. Menghitung jarak terdekat centroid

d. Mengelompokkan data ke masing-masing cluster

6. Menguji Dan Analisa Hasil

Penulis melakukan pelatihan dan pengujian setelah melakukan pengumpulan data, proses ke algoritma K-Means clustering, dan penginstalan software yang akan digunakan yaitu RipedMiner, untuk selanjutnya melakukan pelatihan dan pengujian terhadap data. Pengujian adalah data yang diperoleh dari pemprosesan data awal dengan menggunakan metode $K$-Means clustering. Hasil yang diperoleh dari pengujian kemudian akan dianalisa agar kondisi lebih akurat.

7. Hasil Dan Pembahasan

Kesimpulan hasil dari pengelompokan kualitas minyak kelapa sawit berdasarkan air, kotoran dan asam lemak bebas menjadi baik, sangat baik dan kurang baik, dengan menggunakan metode K-Means clustering dari tahapan proses menguji dan analisa hasil, sehingga menghasilkan kesimpulan yang baik. Untuk mengetahui apakah model yang dirancang tersebut sesuai dengan yang diharapkan.

\section{Hasil dan Diskusi}

Dari Knowledge Discovery in Database (KDD), algoritma K-Means Clustering dapat kita pahami bahwa langkah-langkah penyelesaiannya dapat dijelaskan sebagai berikut :

1. Proses Seleksi Data

Dalam proses Knowledge Discovery in Database (KDD) seleksi data merupakan proses himpunan data dan menciptakan data target pada sampel data, dimana penemuan akan dilakukan selanjutnya hasil seleksi disimpan dalam suatu berkas yang terpisah dari data basis data operasional. Setelah data didapatkan dari pihak PT. Tasma Puja seperti data awal diatas maka dilakukan proses seleksi data, proses ini dilakukan agar memudahkan proses perhitungan 
algoritma $\mathrm{K}$-Means Clustering. Adapun data yang digunakan adalah data pada bulan Desember 2017 yang dapat dilihat pada tabel sebagai berikut :

Tabel 1 : Daftar Seleksi Data Bulan Desember

\begin{tabular}{|c|c|c|c|}
\hline NO & Air & Kotoran & ALB \\
\hline 1 & 0.280 & 0.019 & 3.610 \\
\hline 2 & 0.000 & 0.000 & 0.000 \\
\hline 3 & 0.000 & 0.000 & 0.000 \\
\hline 4 & 0.320 & 0.019 & 3.520 \\
\hline 5 & 0.310 & 0.019 & 3.750 \\
\hline 6 & 0.260 & 0.019 & 3.200 \\
\hline 7 & 0.340 & 0.019 & 3.370 \\
\hline 8 & 0.320 & 0.019 & 3.510 \\
\hline 9 & 0.290 & 0.010 & 3.840 \\
\hline 10 & 0.000 & 0.000 & 0.000 \\
\hline 11 & 0.230 & 0.019 & 4.340 \\
\hline 12 & 0.350 & 0.019 & 4.040 \\
\hline 13 & 0.350 & 0.018 & 3.810 \\
\hline 14 & 0.310 & 0.018 & 3.600 \\
\hline 15 & 0.450 & 0.019 & 3.990 \\
\hline 16 & 0.340 & 0.019 & 3.710 \\
\hline 17 & 0.000 & 0.000 & 0.000 \\
\hline 18 & 0.280 & 0.019 & 3.560 \\
\hline 19 & 0.290 & 0.020 & 4.160 \\
\hline 20 & 0.240 & 0.019 & 3.460 \\
\hline 21 & 0.300 & 0.019 & 3.940 \\
\hline 22 & 0.310 & 0.019 & 3.960 \\
\hline 23 & 0.270 & 0.019 & 4.120 \\
\hline 24 & 0.270 & 0.019 & 4.310 \\
\hline 25 & 0.000 & 0.000 & 0.000 \\
\hline 26 & 0.240 & 0.019 & 4.790 \\
\hline 27 & 0.300 & 0.019 & 4.190 \\
\hline 28 & 0.270 & 0.019 & 4.080 \\
\hline 29 & 0.300 & 0.018 & 4.540 \\
\hline 30 & 0.320 & 0.018 & 4.310 \\
\hline 31 & 0.000 & 0.000 & 0.000 \\
\hline & & & \\
\hline
\end{tabular}

2. Input Data

Data yang diinputkan adalah data yang telah didapat dari PT. Tasma Puja bulan desember tahun 2017 yang dapat di lihat pada tabel 1 diatas. Sebelum dilakukan input data kesistem harus dianalisa dan melakukan proses perhitungan secara benar, adapun proses dari algoritma $K$ Means Clustering adalah sebagai berikut :

a. Menentukan jumlah cluster $(K)$

$\mathrm{K}$ disini adalah sebagai jumlah cluster yang akan dibentuk, pada penelitian ini dibentuk 3 jenis cluster yakni air, kotoran dan asam lemak bebas yang didapat dari rekapitulasi data bulanan mutu CPO PT. Tasma Puja yang diambil pada bulan Desember 2017, cluster tersebut terbagi menjadi baik, sangat baik dan kurang baik.

b. Menentukan Titik Pusat Centroid Secara Random

Setelah menentukan jumlah cluster sebanyak 3 cluster, maka selanjutnya ditentukanlah titik pusat secara random disini diambil untuk Pusat cluster $0\left(\mathrm{C}_{0}\right)$ : di ambil dari nomor 20 untuk Pusat cluster $1\left(\mathrm{C}_{1}\right)$ : di ambil dari nomor 26 dan Pusat cluster $2\left(\mathrm{C}_{2}\right)$ : di ambil dari nomor 6 dapat dilihat dari tabel nilai random sebagai berikut :

Tabel 2 : Nilai Centroid Random

\begin{tabular}{|c|c|c|c|}
\hline Centroid & Air & Kotoran & ALB \\
\hline $\mathbf{C}_{\mathbf{0}}$ & 0,240 & 0,019 & 3,460 \\
\hline
\end{tabular}




\begin{tabular}{|l|l|l|l|}
$\mathbf{C}_{\mathbf{1}}$ & 0,240 & 0,019 & 4,790 \\
\hline $\mathbf{C}_{\mathbf{2}}$ & 0,260 & 0,019 & 3,200 \\
\hline
\end{tabular}

c. Menghitung Jarak Terdekat Centroid

Rumus jarak euclidean distance digunakan untuk menghitung jarak-jarak objek kepusat terhadap masing-masing centroid sehingga ditemukan jarak yang paling terdekat dari setiap data dengan centroid. Berikut rumus persamaan Mengelompokkan data masing-masing cluster Mengklasifikasikan setiap data berdasarkan kedekatannya dengan centroid jarak terpendek. Adapun proses hitungnya sebagai berikut :

1) Proses Iterasi I (Pertama)

Untuk menghitung pusat cluster 0 , cluster 1 dan cluster 2 pada tahapan ini akan dihitung jarak setiap data kemasing-masing centroid menggunakan rumus Euclidean Distance (D) iterasi pertama. Menghitung jarak masing-masing data ke titik pusat sebagai berikut :

1. Proses Hitung cluster $\left(\mathrm{C}_{0}\right)$

a. Pada stage (D1), jarak dengan titik pusat cluster $\left(\mathrm{C}_{0}\right)$ yaitu :

$\mathrm{D}_{1}=\sqrt{\left(1_{\mathrm{x}}-\mathrm{C}_{1 \mathrm{x}}\right)^{2}+\left(1_{\mathrm{y}}-\mathrm{C}_{1 \mathrm{v}}\right)^{2}+\left(1_{\mathrm{z}}-\mathrm{C}_{1 \mathrm{z}}\right)^{2}}$

$=\sqrt{(0,280-0,240)^{2}+(0,019-0,019)^{2}+(3,610-3,460)^{2}}$

$\mathbf{= 0 , 1 5 5}$

b. Pada stage (D2), jarak dengan titik pusat cluster $\left(\mathrm{C}_{0}\right)$ yaitu :

$\mathrm{D}_{1}=\sqrt{\left(1_{\mathrm{x}}-\mathrm{C}_{1 \mathrm{x}}\right)^{2}+\left(1_{\mathrm{y}}-\mathrm{C}_{1 \mathrm{y}}\right)^{2}+\left(1_{\mathrm{z}}-\mathrm{C}_{1 \mathrm{z}}\right)^{2}}$

$=\sqrt{(0,0-0,240)^{2}+(0,0-0,019)^{2}+(0,0-3,460)^{2}}$

$=\mathbf{3 , 4 6 8}$

2. Proses Hitung cluster $\left(\mathrm{C}_{1}\right)$

a. Pada stage $\left(\mathrm{D}_{1}\right)$, jarak dengan titik pusat cluster $\left(\mathrm{C}_{1}\right)$ yaitu :

$\mathrm{D}_{1}=\sqrt{\left(1_{\mathrm{x}}-\mathrm{C}_{2 \mathrm{x}}\right)^{2}+\left(1_{\mathrm{y}}-\mathrm{C}_{2 \mathrm{y}}\right)^{2}+\left(1_{\mathrm{z}}-\mathrm{C}_{2 \mathrm{z}}\right)^{2}}$

$=\sqrt{(0,280-0,240)^{2}+(0,019-0,019)^{2}+(3,610-4,790)^{2}}$

$=\mathbf{1 , 1 8 1}$

b. Pada stage $\left(\mathrm{D}_{2}\right)$, jarak dengan titik pusat cluster $\left(\mathrm{C}_{1}\right)$ yaitu :

$\mathrm{D}_{2} \quad=\sqrt{\left(2_{\mathrm{x}}-\mathrm{C}_{2 \mathrm{x}}\right)^{2}+\left(2_{\mathrm{y}}-\mathrm{C}_{2 \mathrm{y}}\right)^{2}+\left(2_{\mathrm{z}}-\mathrm{C}_{2 \mathrm{z}}\right)^{2}}$

$=\sqrt{(0,0-0,240)^{2}+(0,0-0,019)^{2}+(0,0-4,790)^{2}}$

$$
\mathbf{= 4 , 7 9 6}
$$

3. Proses Hitung cluster $\left(\mathrm{C}_{2}\right)$

a. Pada stage (D1), jarak dengan titik pusat cluster $\left(\mathrm{C}_{2}\right)$ yaitu :

$\mathrm{D}_{1}=\sqrt{\left(1_{\mathrm{x}}-\mathrm{C}_{0 \mathrm{x}}\right)^{2}+\left(1_{\mathrm{y}}-\mathrm{C}_{0 \mathrm{y}}\right)^{2}+\left(1_{\mathrm{z}}-\mathrm{C}_{0 \mathrm{z}}\right)^{2}}$

$=\sqrt{(0,280-0,260)^{2}+(0,019-0,019)^{2}+(3,610-3,200)^{2}}$

$\mathbf{= 0 , 4 1 0}$

b. Pada stage (D2), jarak dengan titik pusat cluster $\left(\mathrm{C}_{2}\right)$ yaitu :

$\mathrm{D}_{1}=\sqrt{\left(1_{\mathrm{x}}-\mathrm{C}_{0 \mathrm{x}}\right)^{2}+\left(1_{\mathrm{v}}-\mathrm{C}_{0 \mathrm{v}}\right)^{2}+\left(1_{\mathrm{z}}-\mathrm{C}_{0 \mathrm{z}}\right)^{2}}$

$=\sqrt{(0,0-0,260)^{2}+(0,0-0,019)^{2}+(0,0-3,200)^{2}}$

$=3,211$

Lakukan proses perhitungan data diatas sampai sebanyak 31 kali sesuai banyaknya data, hasil perhitungannya bisa dilihat pada tabel 3 didapatkan dari perhitungan Euclidean Distance pada iterasi I diatas maka didapatkan perbandingan jarak dari masing-masing cluster $\mathrm{C}_{0}, \mathrm{C}_{1}, \mathrm{C}_{2}$.

d. Mengelompokkan Data Ke Masing-Masing Cluster

Setelah data telah diproses dan dihitung pada langkah-langkah diatas maka hasil dari proses diatas dikelompokan menjadi sebagai berikut :

Tabel 3 : Pengelompokkan Data Cluster dengan Jarak Terdekat

\begin{tabular}{|c|c|c|c|c|c|c|}
\hline No & $\mathbf{C}_{\mathbf{0}}$ & $\mathbf{C}_{\mathbf{1}}$ & $\mathbf{C}_{\mathbf{2}}$ & $\begin{array}{c}\text { Jarak } \\
\text { terdekat } \mathbf{C}_{\mathbf{0}}\end{array}$ & $\begin{array}{c}\text { Jarak } \\
\text { terdekat } \mathbf{C}_{\mathbf{1}}\end{array}$ & $\begin{array}{c}\text { Jarak } \\
\text { terdekat } \mathbf{C}_{\mathbf{2}}\end{array}$ \\
\hline 1 & 0.155 & 1.181 & 0.410 & 1 & & \\
\hline 2 & 3.468 & 4.796 & 3.211 & & & 1 \\
\hline 3 & 3.468 & 4.796 & 3.211 & & & 1 \\
\hline 4 & 0.100 & 1.273 & 0.326 & 1 & & \\
\hline 5 & 0.298 & 1.042 & 0.552 & 1 & & \\
\hline
\end{tabular}




\begin{tabular}{|c|c|c|c|c|c|c|}
\hline 6 & 0.261 & 1.590 & 0.000 & & & 1 \\
\hline 7 & 0.135 & 1.424 & 0.188 & 1 & & \\
\hline 8 & 0.094 & 1.282 & 0.316 & 1 & & \\
\hline 9 & 0.383 & 0.951 & 0.641 & 1 & & \\
\hline 10 & 3.468 & 4.796 & 3.211 & & & 1 \\
\hline 11 & 0.880 & 0.450 & 1.140 & & 1 & \\
\hline 12 & 0.590 & 0.758 & 0.845 & 1 & & \\
\hline 13 & 0.367 & 0.986 & 0.617 & 1 & & \\
\hline 14 & 0.157 & 1.192 & 0.403 & 1 & & \\
\hline 15 & 0.570 & 0.827 & 0.813 & 1 & & \\
\hline 16 & 0.269 & 1.085 & 0.516 & 1 & & \\
\hline 17 & 3.468 & 4.796 & 3.211 & & & 1 \\
\hline 18 & 0.108 & 1.231 & 0.361 & 1 & & \\
\hline 19 & 0.702 & 0.632 & 0.960 & & 1 & \\
\hline 20 & 0.000 & 1.330 & 0.261 & 1 & & \\
\hline 21 & 0.484 & 0.852 & 0.741 & 1 & & \\
\hline 22 & 0.505 & 0.833 & 0.762 & 1 & & \\
\hline 23 & 0.661 & 0.671 & 0.920 & 1 & & \\
\hline 24 & 0.851 & 0.481 & 1.110 & & 1 & \\
\hline 25 & 3.468 & 4.796 & 3.211 & & & 1 \\
\hline 26 & 1.330 & 0.000 & 1.590 & & 1 & \\
\hline 27 & 0.732 & 0.603 & 0.991 & & 1 & \\
\hline 28 & 0.621 & 0.711 & 0.880 & 1 & & \\
\hline 29 & 1.082 & 0.257 & 1.341 & & 1 & \\
\hline 30 & 0.854 & 0.487 & 1.112 & & 1 & \\
\hline 31 & 3.468 & 4.796 & 3.211 & & & 1 \\
\hline \multicolumn{4}{|c|}{ Jumlah } & 17 & 7 & 7 \\
\hline
\end{tabular}

Bedasarkan proses hitung yang didapatkan pada iterasi I sesuai dengan tabel 4.4 diatas maka telah diperoleh cluster dari masing-masingnya dimana hasil dari $\mathrm{C}_{0}$ berjumlah 17 data, hasil dari $\mathrm{C}_{1}$ sebanyak 7 data dan hasil dari $\mathrm{C}_{2}$ sebanyak 7 data.

2) Proses Iterasi II (Kedua)

Dari tabel 4.4 diatas maka didapatkanlah kelompok dari anggota $C_{0}, C_{1}$ dan $C_{2}$ yang mana hasil kelompok ini untuk mendapatkan nilai centroid baru sebagai berikut :

a. Anggota cluster $0\left(\mathrm{C}_{0}\right)$ terdiri dari 17 anggota

$$
\begin{aligned}
& \mathrm{C}_{1}\left(\mathrm{X}_{1}\right)=\frac{(0,280+0,320+0,310+0,340+0,320+0,290+0,350+0,350+0,310+0,450}{+0,340+0,280+0,240+0,300+0,310+0,270+0,270) / 17} \\
& \mathrm{C}_{1}\left(\mathrm{X}_{1}\right)=\frac{\mathbf{0 , 3 1 4}}{\mathrm{C}_{1}\left(\mathrm{Y}_{2}\right)}=\frac{(0,019+0,019+0,019+0,019+0,019+0,010+0,019+0,018+0,018+0,019}{+0,019+0,019+0,019+0,019+0,019+0,019+0,019) / 17} \\
& \mathrm{C}_{1}\left(\mathrm{Y}_{2}\right)=\frac{\mathbf{0 , 0 1 8}}{\mathrm{C} 1\left(\mathrm{Z}_{3}\right)}=\frac{(3,610+3,520+3,750+3,370+3,510+3,840+4,040+3,810+3,600+3,990}{+3,710+3,560+3,460+3,940+3,960+4,120+4,080) / 17} \\
& \mathrm{C}_{1}\left(\mathrm{Z}_{3}\right)=\frac{\mathbf{3 , 7 5 7}}{}
\end{aligned}
$$

b. Anggota cluster $1\left(\mathrm{C}_{1}\right)$ terdiri dari 7 anggota

$$
\begin{array}{ll}
\mathrm{C}_{2}\left(\mathrm{X}_{1}\right) & =\frac{(0,230+0,290+0,270+0,240+0,300+0,300+0,320)}{7} \\
\mathrm{C}_{2}\left(\mathrm{X}_{1}\right) & =\mathbf{0 , 2 7 9} \\
\mathrm{C}_{2}\left(\mathrm{Y}_{2}\right) & =\frac{(0,019+0,020+0,019+0,019+0,019+0,018+0,018)}{7} \\
\mathrm{C}_{2}\left(\mathrm{Y}_{2}\right) & =\mathbf{0 , 0 1 9} \\
\mathrm{C}_{2}\left(\mathrm{Z}_{3}\right) & =\frac{(4,340+4,160+4,310+4,790+4,190+4,540+4,310)}{7} \\
\mathrm{C}_{2}\left(\mathrm{Z}_{3}\right) & =\mathbf{4 , 3 7 7}
\end{array}
$$


c. Anggota cluster $2\left(\mathrm{C}_{2}\right)$ terdiri dari 7 anggota

$$
\begin{array}{ll}
\mathrm{C}_{0}\left(\mathrm{X}_{1}\right) & =\frac{(0,0+0,0+0,260+0,0+0,0+0,0+0,0)}{7} \\
\mathrm{C}_{0}\left(\mathrm{X}_{1}\right) & =\mathbf{0 , 0 3 7} \\
\mathrm{C}_{0}\left(\mathrm{Y}_{2}\right) & =\frac{(0,0+0,0+0,019+0,0+0,0+0,0+0,0)}{7} \\
\mathrm{C}_{0}\left(\mathrm{Y}_{2}\right) & =\mathbf{0 , 0 0 3} \\
\mathrm{C}_{0}\left(\mathrm{Z}_{3}\right) & =\frac{(0,0+0,0+3,200+0,9+0,9+0,9+0,9)}{7} \\
\mathrm{C}_{0}\left(\mathrm{Z}_{3}\right) & =\mathbf{0 , 4 5 7}
\end{array}
$$

Setelah proses perhitungan diatas selesai, maka akan diperoleh centroid baru yang dapat di lihat pada tabel 4.5 dengan nilai sebagai berikut :

Tabel 4 : Nilai Centroid Baru Iterasi ke II

\begin{tabular}{|c|c|c|c|}
\hline Centroid & Air & Kotoran & ALB \\
\hline $\mathbf{C}_{\mathbf{0}}$ & 0,314 & 0,018 & 3,757 \\
\hline $\mathbf{C}_{\mathbf{1}}$ & 0,279 & 0,019 & 4,377 \\
\hline $\mathbf{C}_{\mathbf{2}}$ & 0,037 & 0,003 & 0,457 \\
\hline
\end{tabular}

Setelah didapatkan centroid baru selanjutnya dilakukan iterasi kembali seperti proses perhitungan diatas dengan cara menghitung pusat cluster 0 , cluster 1 dan cluster 2 kemasing-masing centroid menggunakan rumus Euclidean Distance (D) pada iterasi II, proses diatas diulangi sampai iterasi tersebut tidak berubah nilai centroid pada iterasi sebelum dan sesudahnya, pada penelitian ini berhenti pada iterasi ke 7 setelah nilai centroid tidak berubah. Maka hasilnya didapat bahwa cluster $0\left(\mathrm{C}_{0}\right)$ untuk kualitas baik terdapat 12 data, cluster $1\left(\mathrm{C}_{1}\right)$ untuk kualitas sangat baik terdapat 13 data dan cluster $2\left(\mathrm{C}_{2}\right)$ untuk kualitas kurang baik terdapat 6 data. Lebih jelasnya pengelompokan kualitas minyak kelapa sawit dapat dilihat pada tabel 5 sebagai berikut :

Tabel 5 : Hasil Pengelompokan Keseluruhan

\begin{tabular}{|c|c|c|c|c|}
\hline NO & AIR & KOTORAN & ALB & KEPUTUSAN \\
\hline 1 & 0.280 & 0.019 & 3.610 & Baik \\
\hline 2 & 0.000 & 0.000 & 0.000 & Kurang Baik \\
\hline 3 & 0.000 & 0.000 & 0.000 & Kurang Baik \\
\hline 4 & 0.320 & 0.019 & 3.520 & Baik \\
\hline 5 & 0.310 & 0.019 & 3.750 & Baik \\
\hline 6 & 0.260 & 0.019 & 3.200 & Baik \\
\hline 7 & 0.340 & 0.019 & 3.370 & Baik \\
\hline 8 & 0.320 & 0.019 & 3.510 & Baik \\
\hline 9 & 0.290 & 0.010 & 3.840 & Baik \\
\hline 10 & 0.000 & 0.000 & 0.000 & Kurang Baik \\
\hline 11 & 0.230 & 0.019 & 4.340 & Sangat Baik \\
\hline 12 & 0.350 & 0.019 & 4.040 & Sangat Baik \\
\hline 13 & 0.350 & 0.018 & 3.810 & Baik \\
\hline 14 & 0.310 & 0.018 & 3.600 & Baik \\
\hline 15 & 0.450 & 0.019 & 3.990 & Sangat Baik \\
\hline 16 & 0.340 & 0.019 & 3.710 & Baik \\
\hline 17 & 0.000 & 0.000 & 0.000 & Kurang Baik \\
\hline 18 & 0.280 & 0.019 & 3.560 & Baik \\
\hline 19 & 0.290 & 0.020 & 4.160 & Sangat Baik \\
\hline 20 & 0.240 & 0.019 & 3.460 & Baik \\
\hline 21 & 0.300 & 0.019 & 3.940 & Sangat Baik \\
\hline 22 & 0.310 & 0.019 & 3.960 & Sangat Baik \\
\hline 23 & 0.270 & 0.019 & 4.120 & Sangat Baik \\
\hline 24 & 0.270 & 0.019 & 4.310 & Sangat Baik \\
\hline 25 & 0.000 & 0.000 & 0.000 & Kurang Baik \\
\hline 26 & 0.240 & 0.019 & 4.790 & Sangat Baik \\
\hline 27 & 0.300 & 0.019 & 4.190 & Sangat Baik \\
\hline
\end{tabular}




\begin{tabular}{|l|l|l|l|l|}
28 & 0.270 & 0.019 & 4.080 & Sangat Baik \\
\hline 29 & 0.300 & 0.018 & 4.540 & Sangat Baik \\
\hline 30 & 0.320 & 0.018 & 4.310 & Sangat Baik \\
\hline 31 & 0.000 & 0.000 & 0.000 & Kurang Baik \\
\hline
\end{tabular}

\section{Kesimpulan}

Metode K-Means Clustering berhasil diterapkan untuk mengelompokkan kualitas minyak kelapa sawit yang terdiri dari kriteria baik, sangat baik dan kurang baik. Hasil dari penelitian ini dapat mempermudah PT Tasma Puja dalam menentukan kualitas minyak kelapa sawit. Berdasarkan data yang digunakan untuk mengelompokan kualitas minyak kelapa sawit pada bulan desember 2017 dengan jumlah 31 data. Mendapatkan hasil pengelompokkkan bahwa cluster $0\left(\mathrm{C}_{0}\right)$ untuk kualitas baik terdapat 12 data, cluster $1\left(\mathrm{C}_{1}\right)$ untuk kualitas sangat baik terdapat 13 data dan cluster $2\left(\mathrm{C}_{2}\right)$ untuk kualitas kurang baik terdapat 6 data.

\section{Referensi}

[1] Krisdiarto, A.W., Sutiarso, Lilik., Widodo, K.H. (2017). “Optimasi Kualitas Tandan Buah Segar Kelapa Sawit Dalam Proses Panen-Angkut Menggunakan Model Dinamis", AGRITECH, Vol. 37, No. 1, Februari 2017, ISSN : 0216-0455. https://doi.org/10.22146/agritech.17015

[2] Muzakir, Ari.,Wulandari, R.A. (2016). "Model Data Mining Sebagai Prediksi Penyakit Hipertensi Kehamilan Dengan Teknik Decision Tree", Scientific Journal of Informatics Vol. 3, No. 1, Mei 2016 ISSN : 2407-7658. htpps://doi.org/ 10.15294/sji.v3i1.4610

[3] Abdullah., Usman., Efendi, M. (2017). "Sistem Klasifikasi Kualitas Kopra Berdasarkan Warna Dan Tekstur Menggunakan Metode Nearest Mean Classifier (NMC)”, Jurnal Teknologi Informasi dan Ilmu Komputer (JTIIK) Vol.4, No.4, Desember 2017, hlm. 297-303 ISSN: 2355-7699. https://doi.org/10. 25126/jtiik.201744479

[4] Nasari, Fina., Sianturi, C.J.M. (2016). "Penerapan Algoritma K-Means Clustering Untuk Pengelom pokkan Penyebaran Diare Di Kabupaten Langkat", Cogito Smart Journal/Vol. 2/No. 2/Desember 2016. htpps://doi.org/2016;2(2):108-119

[5] Hakim, Lukman., Seruni, Harvin. (2018). "Indikasi Penyimpangan Laporan Keuangan Akademik Universitas XYZ Menggunakan Algoritma Greedy dan K-Means", Jurnal Rekayasa Sistem dan Teknologi Informasi, Vol. 2, No. 1 (2018) 308-313. https://doi.org/10.29207/resti.v2i1.261

[6] Nishom.M.,Fathoni,M.Y.(2018)."Implementasi Pendekatan Rule-Of-Thumb untuk Optimasi Algorit ma K-Means Clustering", Jurnal Pengembangan IT Vol. 3, No.2. https://doi.org/10.30591/jpit.v3i2.909

[7] Sulastri, Heni., Gufroni, A.I. (2017). "Penerapan Data Mining Dalam Pengelompokkan Penderita Thalassemia”, Jurnal Teknologi dan Sistem Informasi - Vol. 03 No. 02 (2017) 299-305. https://doi.org/10.25077/ TEKNOSI.v3i2.2017.299-305 